\title{
PREVALENCE OF HELICOBACTER PYLORI
}

\section{INFECTION AMONG FARMERS AND NON-FARMERS}

\section{WITH DYSPEPSIA}

\author{
By \\ Salem $\mathrm{E}^{1}$, Sakr $\mathrm{A}^{2}$, Younis $\mathrm{F}^{1}$ and Mohamed $\mathrm{A}^{3}$ \\ ${ }^{1}$ Department of Public Heath and Community Medicine, ${ }^{2}$ Department of Tropical Medicine, \\ ${ }^{3}$ Department of Pathology, Faculty of Medicine, Menoufia University, Egypt
}

SalemE:dr_eman53@yahoo.com

Younis F: fatenyounis@yahoo.com
SakrA: aymanahmedsakr@gmail.com

Mohamed A: asmaasham@rocketmail.com

\begin{abstract}
Introduction: Helicobacter pylori (H pylori) is a gram negative spirally shaped bacterium. It is known to be the most common cause of dyspepsia especially in developing countries as Egypt. Aim of work: To identify the prevalence of $\mathrm{H}$ pylori among patients with dyspepsia especially farmers and the infection risk factors. Materials and methods: This is a hospital based cross-sectional study conducted on 152 patients (78 farmers and 74 non-farmers) with dyspepsia among those admitted to Gastrointestinal (GI) Endoscopy Unit at Menoufia University hospital, Menoufia, Egypt. They were recruited to this study from $1^{\text {st }}$ September 2017 to the end of May 2018. Designed questionnaire, clinical examination, esophago-gastro-duodenoscopy (EGD) and histopathological evaluation were conducted to the studied patients. Results: The overall prevalence rate of $\mathrm{H}$ pylori among dyspeptic patients in the current study was (73.7\%) and significantly higher among low levels of education (28.6\%), female gender $(69.6 \%)$, farmers occupation $(57.1 \%)$, low socioeconomic status $(28.6 \%)$, who consume tap water for drinking (76.8\%) and unwashed vegetables (73.2\%). Epigastric pain was more common in patients with $\mathrm{H}$ pylori $(\mathrm{P}<0.001)$. Also, acid reflux, morning vomiting and upper abdominal distention were significantly more prevalent among $\mathrm{H}$ pylori positive cases. About (82.1\%) of farmers were significantly positively infected than non-farmers $(64.9 \%)$. Illiterate female farmers who didn't wash vegetables and with history of peptic ulcers were more susceptible of infection. Conclusion:
\end{abstract}


Farmers occupation was at risk of $\mathrm{H}$ pylori infection than non-farmers. Illiteracy, bad sanitation and low hygienic standard were the risk factors of infection. Health education and environmental sanitation are recommended to lower the prevalence of $\mathrm{H}$ pylori especially among farmers.

Key words: H pylori, Farmers, Dyspepsia, Esophago-gastro-duodenoscopy and Risk factors

\section{Introduction}

Dyspepsia is one of the most common digestive complaint in the general population and recently defined by Room IV criteria as any combination of 4 symptoms: postprandial fullness, early satiety, epigastric burning and epigastric pain that are severe enough to interfere with the usual activities for at least one day (post-prandial fullness and early satiation) or three days (epigastric burning and pain) per week on the last 3 months with an onset of at least 6 months previously (Stanghellini et al., 2016)

Studies have indicated that Helicobacter pylori (H pylori) typically infect the gastric mucosa, and so their presence is associated with a variety of gastrointestinal diseases including gastritis, duodenal and gastric ulcers, non-ulcer dyspepsia, and gastric adenocarcinoma and lymphoma (Zhong et al., 2016). The main route of H pylori transmission is still unknown. Studies show that, $\mathrm{H}$ pylori bacteria can spread directly from one person to the other, or indirectly from an infected person to the environment. Person to person transmission is divided into fecal-oral, gastric-oral and oral-oral (Zamani et al., 2017).

$\mathrm{H}$ pylori infection has a high prevalence globally, ranging from 50 to $80 \%$, usually acquired early in life and characterized by long incubation period. Most of the infected cases remain asymptomatic for decades. Clinically presented cases are commonly associated with gastritis and peptic ulcer disease (Kao et al., 2016).

Farmers have a greater exposure to environmental contaminants than non-farmers. Moreover, farmers might neglect washing of their farm products and raw vegetables before consumption also, might consume raw farm milk without boiling or pasteurization which could be a source of $\mathrm{H}$ pylori infection as reported by Fujimura et al., 2002.

$\mathrm{H}$ pylori were suggested as a zoonotic disease by some researchers who isolated $\mathrm{H}$ pylori from sheep (Dore et al., 2001). Cattle, sheep and goats 
are frequently reared by the Egyptian farmers and sometimes they breed these animals at home which raise the risk of farmers' exposure to zoonotic diseases. Also, Safaei et al., 2011 detected H pylori antigen from milk and feces of cows and raised the possibility of fecal contamination of food as a mode of transmission of the bacteria from animals.

Little information was known about the prevalence and determinants of $\mathrm{H}$ pylori infection among Egyptian farmers so this study was carried out to clarify this issue.

\section{Aim of work}

To identify the prevalence of $\mathrm{H}$ pylori among patients with dyspepsia especially farmers and the infection risk factors.

\section{Materials and methods}

- Study design: This is a comparative cross -sectional study.

\section{- Place and duration of the study: This} study was conducted on adult patients with dyspepsia who were referred to the Gastrointestinal Endoscopy Unit at Menoufia University hospital, Egypt during the period from $1^{\text {st }}$ September 2017 to the end of May 2018.

- Study sample: A total of 165 patients were examined, 152 (78 farmers and 74 non-farmers) were enrolled in this study after exclusion of non-respondent and application of exclusion criteria with a response rate about $92.7 \%$. A farmer in this study defined as a person who engaged in agriculture and raising animals for food or raw materials either being the owner of the farmed land or might work as a laborer on land owned by others (Dyer, 2007). While, nonfarmers were individuals who didn't engaged in farm work.

Patients included in the study were selected based on Room IV criteria of dyspepsia (Stanghellini et al., 2016) and not responding to standard medical therapy.

Exclusion criteria included: patients underwent esophago-gastroduodenoscopy (EGD) for indications other than dyspepsia as anemia, reflux symptoms, vomiting or those who had proton pump inhibitors or took antibiotics specific for $\mathrm{H}$ pylori eradication for 2 weeks prior to EGD. Also, patients who refused or were unfit for endoscopy were also excluded.

\section{- Study methods:}

All participants were interviewed by the authors at the outpatient of 
Gastroenterology clinic and GI Endoscopy Unit of Tropical Medicine department in the studied hospital and subjected to the following:

\section{I: Structured interview questionnaire:}

This tool was developed and used by the researchers based on the review of the relevant literature. It included sociodemographic data (age, sex, education levels, occupation, and smoking habit), source of drinking water and household hygienic practices. Gastrointestinal symptoms were evaluated from the questionnaires completed by the patients from the questions concerning dyspeptic symptoms (epigastric pain, acid reflux, nausea, vomiting, melena, hematemesis, post-prandial belching)

The socio-economic status was assessed using a scoring system developed by Fahmy and El-Sherbini (1983). It includes seven items scoring system with a total score of 42 . It includes father's education and work, mother's education and work, monthly income, crowding index and sanitation. It was classified as: high socioeconomic class (with score from 42-36), middle socioeconomic class (with score from 35-27) and low socioeconomic class (with score from 26-21) and very low socioeconomic (with score from <21)

\section{II: Clinical examination:}

All enrolled patients with dyspepsia were subjected to clinical examination with special stress on upper abdominal signs.

\section{III: Upper GI endoscopy assessment:}

All the studied patients underwent EGD till the second part of duodenum. All EGDs performed by a single gastrointestinal endoscopist. The scopes used were GIF 240,260,170 and 180 series of Olympus Co. (Tokyo, Japan) through which gastric mucosa, collecting venules, atypical vascular and mucosal patterns can be clearly observed. Patients were biopsied according to updated Sydney system (two antral biopsies, single biopsy from incisura angularis and two from the lesser and greater curvatures) and sent for histopathology (Tongtawee et al., 2015).

\section{IV: Histopathological evaluation:}

All the obtained biopsies were collected, fixed in $10 \%$ neutral formalin, and sent for preparation of formalinfixed, paraffin-embedded tissue blocks. Sections of 4um thickness were cut. One set of tissue sections was stained with hematoxylin and eosin and the other with Giemsa stain for detection 
of $\mathrm{H}$ pylori in the gastric mucosa. $\mathrm{H}$ pylori appear in Geimsa stained slides as bluish purple rod shaped, curvilinear and/or dot like granular organisms along the luminal surfaces of the epithelium (Pranjal and Kalpana, 2015).

\section{Consent}

Informed formal consent was obtained from each patient involved in the study after they received detailed information concerning the aims of the research work. The study protocol was adherent to practice Guidelines and Declaration of Helsinki (World Medical Association, 2004).

\section{Ethical approval}

The Menoufia Faculty of Medicine Committee for Medical Research Ethics reviewed and formally approved the study.

\section{Data management}

Results were collected, tabulated, statistically analyzed by IBM personal computer and statistical package SPSS version 20. Two types of statistical analyses were performed. Descriptive statistics: e.g., percentage (\%), mean, and standard deviation (SD); and Analytic statistics: Student t- test, which is a test of significance used for comparison between two groups having quantitative variables. Chi-squared $(\chi 2)$ test, was used to study the association between two or more qualitative variables. Binary logistic regression analysis was performed to examine the independent effects of the risk factors on $\mathrm{H}$ pylori infection. The results are shown as Odds ratio (OR) and $95 \%$ confidence interval $(\mathrm{CI})$. A p-value of 0.05 was chosen as a level of significance. 


\section{Results}

Table 1: Determinants of $\mathbf{H}$ pylori infection in patients with dyspepsia.

\begin{tabular}{|c|c|c|c|c|c|}
\hline Items & $\begin{array}{c}\text { H pylori +ve } \\
(\text { No=112) } \\
\text { No }(\%)\end{array}$ & $\begin{array}{c}\text { H pylori -ve } \\
(\text { No }=40) \\
\text { No }(\%)\end{array}$ & $\begin{array}{c}\text { Total } \\
(\text { No }=152) \\
\text { No }(\%)\end{array}$ & $\chi^{2}$ & p-value \\
\hline Age (years) Mean \pm SD & $43.50 \pm 15.83$ & $38.70 \pm 12.54$ & $42.24 \pm 15.15$ & $1.73 \#$ & 0.085 \\
\hline $\begin{array}{l}\text { Sex: } \\
\text { Males } \\
\text { Females }\end{array}$ & $\begin{array}{l}34(30.4) \\
78(69.6) \\
\end{array}$ & $\begin{array}{l}24(60.0) \\
16(40.0) \\
\end{array}$ & $\begin{array}{l}58(38.2) \\
94(61.8) \\
\end{array}$ & 10.98 & $0.001 * *$ \\
\hline $\begin{array}{l}\text { Education levels: } \\
\text { Illiterate } \\
\text { Primary } \\
2^{\text {ry }} \text { and above } \\
\end{array}$ & $\begin{array}{l}32(28.6) \\
26(23.2) \\
54(48.2) \\
\end{array}$ & $\begin{array}{c}2(5.0) \\
4(10.0) \\
34(85.0) \\
\end{array}$ & $\begin{array}{l}34(22.4) \\
30(19.7) \\
88(57.9) \\
\end{array}$ & 16.82 & $<0.001 * *$ \\
\hline $\begin{array}{l}\text { Occupation: } \\
\text { Farmers } \\
\text { Non-farmers } \\
\end{array}$ & $\begin{array}{l}64(57.1) \\
48(42.9) \\
\end{array}$ & $\begin{array}{l}14(35.0) \\
26(65.0) \\
\end{array}$ & $\begin{array}{l}78(51.3) \\
74(48.7) \\
\end{array}$ & 5.78 & $0.016 *$ \\
\hline $\begin{array}{l}\text { Smoking: } \\
\text { Yes } \\
\text { NO } \\
\end{array}$ & $\begin{array}{l}28(25.0) \\
84(75.0) \\
\end{array}$ & $\begin{array}{c}8(20.0) \\
32(80.0) \\
\end{array}$ & $\begin{array}{c}36(23.7) \\
116(76.3) \\
\end{array}$ & 0.41 & 0.523 \\
\hline $\begin{array}{l}\text { Socioeconomic levels: } \\
\text { Low } \\
\text { Middle } \\
\text { High } \\
\end{array}$ & $\begin{array}{l}32(28.6) \\
20(17.9) \\
60(53.6) \\
\end{array}$ & $\begin{array}{c}4(10.0) \\
4(10.0) \\
32(80.0) \\
\end{array}$ & $\begin{array}{l}36(23.7) \\
24(15.8) \\
92(60.5) \\
\end{array}$ & 8.35 & $0.012 *$ \\
\hline $\begin{array}{l}\text { Source of drinking water: } \\
\text { Tap water } \\
\text { Ground water } \\
\text { Bottled or filtered water } \\
\end{array}$ & $\begin{array}{c}86(76.8) \\
24(21.4) \\
2(1.8) \\
\end{array}$ & $\begin{array}{l}24(60.0) \\
4(10.0) \\
12(30.0) \\
\end{array}$ & $\begin{array}{c}110(72.4) \\
18(18.4) \\
14(9.2) \\
\end{array}$ & 28.71 & $<0.001 * *$ \\
\hline $\begin{array}{l}\text { Washing vegetables: } \\
\text { Never } \\
\text { Sometimes } \\
\text { Always } \\
\end{array}$ & $\begin{array}{c}82(73.2) \\
26(23.2) \\
4(3.6) \\
\end{array}$ & $\begin{array}{c}12(40.0) \\
28(70.0) \\
0 \\
\end{array}$ & $\begin{array}{c}4(2.6) \\
54(35.5) \\
94(61.8) \\
\end{array}$ & 28.49 & $<0.001 * *$ \\
\hline $\begin{array}{l}\text { History of PU: } \\
\text { Yes } \\
\text { NO } \\
\end{array}$ & $\begin{array}{l}64(57.1) \\
48(42.9) \\
\end{array}$ & $\begin{array}{l}12(40.0) \\
28(70.0) \\
\end{array}$ & $\begin{array}{l}76(50.0) \\
76(50.0) \\
\end{array}$ & 8.69 & $0.003 * *$ \\
\hline $\begin{array}{l}\text { Family history of PU: } \\
\text { Yes } \\
\text { NO }\end{array}$ & $\begin{array}{l}48(42.9) \\
64(57.1)\end{array}$ & $\begin{array}{c}34(85.0) \\
6(15.0)\end{array}$ & $\begin{array}{l}82(53.9) \\
70(46.1)\end{array}$ & 21.07 & $<0.001 * *$ \\
\hline
\end{tabular}

\# : t-test was used

*: Statistically significant
PU: Peptic ulcer

**: Highly statistically significant 
Table 1 showed that there was a statistically significant difference of $\mathrm{H}$ pylori among low levels of education, female gender, farmers, low socioeconomic status, who consumed tap water for drinking and unwashed vegetables, and who have a past history of peptic ulcer. On the contrary, positive family history of peptic ulcer was significantly lower among the positive cases. However, there was no statistically significant association between the prevalence of $\mathrm{H}$ pylori infection and other factors, such as age and smoking habits.

Table 2: Gastrointestinal symptoms associated with $\mathbf{H}$ pylori infection among patients with dyspepsia.

\begin{tabular}{|l|c|c|c|c|c|}
\hline Gastrointestinal symptoms & $\begin{array}{c}\text { H pylori +ve } \\
\mathbf{( N o = 1 1 2 )} \\
\text { No }(\mathbf{\%})\end{array}$ & $\begin{array}{c}\text { H pylori -ve } \\
\mathbf{( N o = 4 0 )} \\
\text { No (\%) }\end{array}$ & $\begin{array}{c}\text { Total } \\
(\mathbf{N o = 1 5 2}) \\
\text { No (\%) }\end{array}$ & $\chi^{2}$ & p-value \\
\hline Epigastric pain & $104(92.9)$ & $28(70.0)$ & $132(86.8)$ & 13.48 & $<\mathbf{0 . 0 0 1 * *}$ \\
\hline Acid reflux & $58(51.8)$ & $30(75.0)$ & $88(57.9)$ & 6.52 & $\mathbf{0 . 0 1 1 *}$ \\
\hline Nausea & $44(39.3)$ & $14(35.0)$ & $58(38.2)$ & 0.23 & 0.632 \\
\hline Morning vomiting & $46(41.1)$ & $4(10.0)$ & $50(32.9)$ & 12.89 & $<\mathbf{0 . 0 0 1 * *}$ \\
\hline Acid hematemesis & $8(7.1)$ & $6(15.0)$ & $14(9.2)$ & 2.18 & 0.140 \\
\hline Melena & $8(7.1)$ & $8(20.0)$ & $16(10.5)$ & 5.17 & $\mathbf{0 . 0 2 3 *}$ \\
\hline Throat lump sensation & $28(25.0)$ & $18(45.0)$ & $46(30.0)$ & 5.58 & $\mathbf{0 . 0 1 8 *}$ \\
\hline Post-prandial belching & $68(60.7)$ & $24(60.0)$ & $92(60.5)$ & 0.01 & 0.937 \\
\hline Upper abdominal distention & $96(85.7)$ & $22(55.0)$ & $118(77.6)$ & 16.01 & $<\mathbf{0 . 0 0 1 * *}$ \\
\hline Change in bowel habits & $62(55.3)$ & $24(60.0)$ & $86(56.6)$ & 5.20 & $\mathbf{0 . 0 2 3 *}$ \\
\hline $\begin{array}{l}\text { Nocturnal worsening in GI } \\
\text { symptoms }\end{array}$ & $58(51.8)$ & $14(35.0)$ & $72(47.4)$ & 3.33 & 0.068 \\
\hline
\end{tabular}

*: Statistically significant

**: Highly statistically significant

Table 2 showed that epigastric pain, acid reflux, morning vomiting and upper abdominal distention were significantly higher among $\mathrm{H}$ pylori positive cases. There was no association between $\mathrm{H}$ pylori infection and other gastrointestinal symptoms, such as nausea, acid hematemesis, post-prandial belching and nocturnal worsening of GI symptoms. 
Table 3: Prevalence of $\mathbf{H}$ pylori infection among farmers and non- farmers.

\begin{tabular}{|l|c|c|c|c|c|}
\hline \multicolumn{1}{|c|}{ Item } & $\begin{array}{c}\text { Farmers } \\
(\mathbf{N o = 7 8 )} \\
\text { No (\%) }\end{array}$ & $\begin{array}{c}\text { Non-farmers } \\
\mathbf{( N o = 7 4 )} \\
\text { No (\%) }\end{array}$ & $\chi^{2}$ & p-value & $\begin{array}{c}\text { OR } \\
\text { (95\% CI) }\end{array}$ \\
\hline $\begin{array}{l}\text { H pylori: } \\
+\mathrm{ve} \\
-\mathrm{ve}\end{array}$ & $\begin{array}{l}64(82.1) \\
14(17.9)\end{array}$ & $\begin{array}{l}48(64.9) \\
26(35.1)\end{array}$ & 5.78 & $\mathbf{0 . 0 1 6 *}$ & 2.48 \\
\hline
\end{tabular}

OR: Odds ratio

CI: Confidence Interval

*: Statistically significant

Table 3 showed that there was a statistically significant difference of $\mathrm{H}$ pylori among farmers compared to non-farmers $(\mathrm{P}=0.016)$.

Table 4: Determinants of $\mathbf{H}$ pylori infection among farmers' patients.

\begin{tabular}{|c|c|c|c|c|}
\hline \multirow[b]{2}{*}{ Determinants } & \multicolumn{2}{|c|}{ Farmers } & \multirow[b]{2}{*}{$\chi^{2}$} & \multirow[b]{2}{*}{ p-value } \\
\hline & $\begin{array}{c}\text { H pylori +ve } \\
\text { (No }=64) \\
\text { No }(\%) \\
\end{array}$ & $\begin{array}{c}\text { H pylori -ve } \\
\text { (No }=14) \\
\text { No }(\%) \\
\end{array}$ & & \\
\hline Age (years): Mean \pm SD & $44.81 \pm 15.91$ & $37.81 \pm 11.87$ & $1.61 \#$ & 0.113 \\
\hline $\begin{array}{l}\text { Sex: } \\
\text { Males } \\
\text { Females }\end{array}$ & $\begin{array}{l}16(25.0) \\
48(75.0)\end{array}$ & $\begin{array}{l}6(42.9) \\
8(57.1)\end{array}$ & 5.57 & $0.018 *$ \\
\hline $\begin{array}{l}\text { Education levels: } \\
\text { Illiterate } \\
\text { Primary } \\
2^{\text {ry }} \text { and above } \\
\end{array}$ & $\begin{array}{l}22(34.4) \\
24(37.5) \\
18(28.1) \\
\end{array}$ & $\begin{array}{c}2(14.3) \\
0 \\
12(85.7) \\
\end{array}$ & 16.67 & $<0.001 * *$ \\
\hline $\begin{array}{l}\text { Smoking: } \\
\text { Yes } \\
\text { NO }\end{array}$ & $\begin{array}{l}12(18.8) \\
52(81.3)\end{array}$ & $\begin{array}{c}2(14.3) \\
12(85.7)\end{array}$ & 0.16 & 0.693 \\
\hline $\begin{array}{l}\text { Socioeconomic levels: } \\
\text { Low } \\
\text { Middle } \\
\text { High } \\
\end{array}$ & $\begin{array}{l}18(28.1) \\
10(15.6) \\
36(56.3) \\
\end{array}$ & $\begin{array}{l}6(42.9) \\
4(28.6) \\
4(28.6) \\
\end{array}$ & 3.60 & 0.165 \\
\hline $\begin{array}{l}\text { Source of drinking water: } \\
\text { Tap water } \\
\text { Ground water } \\
\text { Bottled or filtered water }\end{array}$ & $\begin{array}{c}46(71.9) \\
16(25.0) \\
2(3.1)\end{array}$ & $\begin{array}{c}12(85.7) \\
0 \\
2(14.3)\end{array}$ & 6.59 & $0.037 *$ \\
\hline $\begin{array}{l}\text { Washing vegetables: } \\
\text { Never } \\
\text { Sometimes } \\
\text { Always } \\
\end{array}$ & $\begin{array}{c}4(6.3) \\
18(28.1) \\
42(65.6) \\
\end{array}$ & $\begin{array}{c}0 \\
10(71.4) \\
4(28.6) \\
\end{array}$ & 9.55 & $0.008 * *$ \\
\hline $\begin{array}{l}\text { History of PU: } \\
\text { Yes } \\
\text { NO }\end{array}$ & $\begin{array}{l}42(65.6) \\
22(34.4)\end{array}$ & $\begin{array}{l}5(35.7) \\
9(64.3)\end{array}$ & 4.29 & 0.038* \\
\hline $\begin{array}{l}\text { Family history of PU: } \\
\text { Yes } \\
\text { NO }\end{array}$ & $\begin{array}{l}22(34.4) \\
42(65.6)\end{array}$ & $\begin{array}{l}6(42.9) \\
8(57.1)\end{array}$ & 2.52 & 0.113 \\
\hline
\end{tabular}

\#: t-test was used

*: Statistically significant
PU: Peptic ulcer

**: Highly statistically significant 
Table 4 showed that female gender, low levels of education, drinking of underground water, non washing of vegetables and past history of peptic ulcer were the most relevant risk factors for infection among farmers.

Table 5: Binary logistic regression analysis for relevant risk factors of $H$. pylori infection among farmers' patients with dyspepsia.

\begin{tabular}{|l|c|c|}
\hline Items & OR (95\% CI) & p-value \\
\hline $\begin{array}{l}\text { Sex: } \\
\text { Males }\end{array}$ & Reference & $\mathbf{0 . 0 4 1 *}$ \\
Females & $1.72(1.36-2.16)$ & $\mathbf{0 . 0 2 7 *}$ \\
\hline Education levels: & $1.96(0.94-0.96)$ & $\mathbf{0 . 0 1 3}$ \\
Illiterate & $1.63(0.47-0.86)$ & \\
Primary & Reference & \\
$2^{\text {ry }}$ and above & & 0.874 \\
\hline Source of drinking water: & & 0.759 \\
Tap & $0.82(0.65-1.03)$ & \\
Ground water & $0.96(0.87-1.60)$ & \\
Bottled or filtered water & Reference & \\
& & \\
\hline Washing vegetables : & Reference & $\mathbf{0 . 0 3 9 *}$ \\
Always & $1.59(1.46-1.78)$ & $\mathbf{0 . 0 3 8 *}$ \\
Sometimes & $10.52(1.15-6.57)$. & $\mathbf{0 . 0 2 6 *}$ \\
Never & $21.87(1.45-3.11)$ & \\
\hline History of PU: & Reference & \\
Yes & & \\
NO & & \\
\hline
\end{tabular}

*: Statistically significant

After applying the binary logistic regression analysis for the previous factors, illiterate patients had 1.96 times higher risk of developing $\mathrm{H}$ pylori infection (95\% CI 0.94-0.96) compared to those 2ry school or more education. Female gender had 1.72 times higher risk of $\mathrm{H}$ pylori infection (95\% CI 1.36-2.16) compared to male. Using of unwashed vegetables had higher risk 10.52 times for infection $(95 \% \mathrm{CI}$ 1.15-6.57). In addition, past history of peptic ulcer was the most implicating risk factor for acquisition of $\mathrm{H}$ pylori infection among farmers of 21.87 times risk (95\% CI 1.45-3.11) as shown in Table 5. 


\section{Discussion}

This study was conducted to determine the prevalence and risk factors of $\mathrm{H}$ pylori infection among farmers and non-farmers dyspeptic patients admitted to the gastrointestinal endoscopy unit at Menoufia University hospital, Egypt.

The overall prevalence of $\mathrm{H}$ pylori infection among dyspeptic patients in the current study was high (112/152 cases, $73.7 \%$; Table 1). This is similar to two recent Egyptian studies done by Dawod and Emara, 2016 and Emara et al., 2017 which revealed that, $\mathrm{H}$ pylori bacilli were histologically detected in $51.4 \%$ and $69.2 \%$ of dyspeptic patients. This emphasizes $\mathrm{H}$ pylori as a common and an important cause of dyspepsia in Egypt. Also, the findings of our work were in agreement with the studies done in other countries as in Afghanistan (75.6\%) (Hamrah et al., 2017), Iran (84.8\%) (Khedmat et al., 2013).

However, our results were higher than that detected among patients in Kuwait (65.7\%) and Ethiopia (49.7\%) (Alazmi et al, 2010; Mathewos et al., 2013; respectively). These differences are most likely may be due to the testing methods, socio-economic status of the studied populations, and geographical variation. Also, our studied cases were diagnosed by histopathological examination of endoscopic biopsy not by serological analysis as the previously mentioned studies.

Our study also revealed that the prevalence of $\mathrm{H}$ pylori infection was associated with lower educational and socioeconomic levels (Table 1). These results were consistent with the work done by Lehours and Yilmax, 2007, who reported that lower socioeconomic class is a common risk factors associated with $\mathrm{H}$ pylori.

The current work showed that there was no statistically significant association between the prevalence of $\mathrm{H}$ pylori infection and age (Table 1), which was in accordance with the study done by Alavi et al., 2011 on their work on $\mathrm{H}$ pylori infection among visitors of cardiac patients in Razi hospital in Ahvaz, Iran. However, another study conducted by Alvarado-Esquivel, 2013 in Mexico found a significant increased in anti-H pylori IgG antibodies in the age groups of 41-50 and 61- 70 years but, logistic regression showed no association between $\mathrm{H}$ pylori infection with age. These contradictory findings might be due to the difference in the studied population and sample size. 
Females in this study had higher prevalence of $\mathrm{H}$ pylori than males (Table 1). This might be explained by the fact that women were more concerned about their health compared to men and tended to report health problems and seek medical care more often. This result agreed with the study conducted by Alwahaibi et al. (2013) in Oman. On the contrary, this finding is in disagreement with other studies in Australia (Windsor et al., 2005) where males had more of $\mathrm{H}$ pylori infection than females and explained this by that males are working outdoor for longer time than females and are more exposed to the environmental risk factors for infection.

On the contrary to the previous studies, Cheng et al., 2009 on their work on the prevalence of $\mathrm{H}$ pylori infection and identification of risk factors in rural and urban Beijing, China detected no significant differences as regards gender, alcohol consumption, or smoking between $\mathrm{H}$ pylori positive and negative individuals.

Bad hygiene as negligence of washing vegetables and raw food was considered as a risk factor for $\mathrm{H}$ pylori in this study (Table 1). In their study on $\mathrm{H}$ pylori in various types of vegetables and salads in Iran, Atapoor et al.
(2014) reported the contamination of basil, spinach, salad, parsley, leek and radish by $\mathrm{H}$ pylori. They suggested that polluted water, feces, animal manure and even soil are the main sources for contamination of vegetables with $\mathrm{H}$ pylori as the higher prevalence of this organism was detected in un-washed vegetables and traditional salads.

Positive history of peptic ulcer (PU) was present among $57.4 \%$ of $\mathrm{H}$ pylori positive cases (Table 1). Similarly, Tarkhashvili, 2009 detected that $\mathrm{H}$ pylori was present in $58 \%$ of patients who had peptic ulcer in Republic of Georgia. While $\mathrm{Vu}$ and $\mathrm{Ng}, 2000$ in their work on the prevalence of $\mathrm{H}$ pylori in peptic ulcer disease in a Singapore hospital, detected a high prevalence $\mathrm{H}$ pylori as it was $67.9 \%$ among of gastric ulcer patients, $85.1 \%$ among duodenal ulcer cases and $85.7 \%$ in combined gastric and duodenal ulcer patients. On the contrary, Whittle et al., 2010 in the Turks and Caicos Islands in India found a lower prevalence as gastric ulcer was present in $40 \%$ and duodenal ulcer was present in $33 \%$ of $\mathrm{H}$ pylori positive cases. These differences between countries might be due to applying different techniques of analysis and different sample size. 
Epigastric pain, morning vomiting and upper abdominal distention were more prevalent in $\mathrm{H}$ pylori positive cases than negative ones (Table 2). Our result was in agreement with other studies done in Egypt by Dawod and Emara, 2016 and in Sudan by Abdallah et al., 2014.

In the present study we found that farmers acquire $\mathrm{H}$ pylori infection $(82.1 \%)$ significantly more than nonfarmers (64.9\%) (Table 3).Also,farming occupation was associated with $\mathrm{H}$ pylori infection among $91.7 \%$ of dyspeptic patients in Ghana (Archampong et al., 2015). Another studies reported the higher prevalence of $\mathrm{H}$ pylori among rural residence in China (Cheng et al., 2009), Australia (Windsor et al., 2005) and Brazil (Zaterka et al., 2007).

The higher prevalence of $\mathrm{H}$ pylori among farmers might suggest possible zoonotic transmission of the bacteria from animals that were breaded by them in Egyptian rural areas such as buffalos, cows and sheep. This suggestion was raised by a previous study conducted by El-Gohary et al., 2015 in Egypt as they isolated $\mathrm{H}$ pylori from cattle feces and milk. In addition, Dore et al., 2001 and Momtaz et al., 2014; revealed the isolation of $\mathrm{H}$ pylori from gastric tissue of several animals such as sheep and cow and presumed them as plausible reservoirs and sources of the infection.

Moreover, the high prevalence of $\mathrm{H}$ pylori observed among farmers in the present study is likely explained by factors which facilitate acquisition of infection, such as inadequate living resources, poor sanitation and a lower level of education. Also, some studies from Brazil (Santos et al., 2005), China (Shi et al., 2008), and Iran (Sheikhian et al., 2011) demonstrated a negative correlation between the rate of infection and the level of education. This observation could explain the higher prevalence of $\mathrm{H}$ pylori among farmers' females where the lower levels of education in rural areas.

Source of drinking water was a significant risk factor for $\mathrm{H}$ pylori infection including tap and wells or underground water (Table 4). A previous study in Egypt provided a some evident on the transmission of $\mathrm{H}$ pylori by drinking water as it was detected in water samples from both tap water and underground water when tracking the DNA of bacteria by PCR technique (El-Sharouny et al., 2015). Also, the waterborne $\mathrm{H}$ pylori infection was mentioned in Nurgalieva et al., 2002 study in Kazakhstan. 
Unsanitary hygienic practice regarding washing of vegetables was a risk factor of acquisition of $\mathrm{H}$ pylori infection among farmers in the current study (Table 4, 5) which could be contaminated by animal wastes that might be used as a manure. Similarly, Bener et al. (2006) on his study about washing of vegetables between farmers and non farmers; reported that fewer farmers washed their harvested products before consumption which may be contaminated with $\mathrm{H}$ pylori and the difference between the two groups was statistically significant.

This study has some limitations. It was a hospital-based study which limits the actual prevalence of $\mathrm{H}$ Pylori infections and the studied factors but it reflects the prevalence among patients with dyspepsia in Egypt. A community based study involving asymptomatic controls was desirable but because endoscopy is expensive and invasive, it was not possible to get study participants. In addition, the small sample size and single center data source might limit the generalizability of this study. Finally, the cross-sectional study makes it difficult to find out causality. Despite these limitations, this study reflects the association between farmer's occupation and $\mathrm{H}$ pylori infection in Egypt. Therefore, these results should be verified with largescale studies.

\section{Conclusion and recommendations:}

This study showed high prevalence $\mathrm{H}$ pylori infection in patients with dyspepsia who were referred to GI endoscopy unit in Menoufia University hospital, Egypt. The risk factors that have a significant association with the prevalence of $\mathrm{H}$ pylori infection in dyspeptic patients are female gender, lower education levels, farmers' occupation, poor water sanitation and hygienic practices. Reducing the rate of $\mathrm{H}$ pylori transmission especially among farmers will require health education, improvements in overall sanitation including clean water and household hygienic practices.

\section{Conflict of interest}

No conflict of interest has been declared.

\section{Funding}

None

\section{Acknowledgment}

We are grateful to the patients who agreed to participate in this study and to the healthcare team at GI endoscopy unit at Menoufia University Hospital, Egypt for their support. 


\section{References}

1. Abdallah $\mathrm{T}$, Mohammed $\mathrm{H}$, Mohammed $\mathrm{M}$ and Ali A (2014): Sero-prevalence and factors associated with Helicobacter pylori infection in Eastern Sudan. Asian Pac J Trop Dis; 4(2): 115-9.

2. Alavi SM, Adel SM and Rajabzadeh AR (2011): Seroprevalence study of Helicobacter pylori infection among visitors of cardiac patients in Razi hospital in Ahvaz, Iran. Jundishapur J Microbiol; 3(1): 28-31

3. Alazmi WM, Siddique I, Alateeqi N and AlNakib B (2010): Prevalence of Helicobacter pylori infection among new outpatients with dyspepsia in Kuwait. BMC Gastroenterol; 10, 14.

4. Alvarado-Esquivel C (2013): Seroepidemiology of Helicobacter pylori infection in Tepehuanos aged 15 years and older in Durango, Mexico. J Pathog Volume 20135 Pages. doi: 10.1155/2013/243246.

5. Alwahaibi NY, Almahrooqi BM and Alrawahi SA (2013): The prevalence of helicobacter pylori and gastritis in Oman. J Dig Endosc; 4: 29-32.

6. Archampong T, Asmah R, Wiredu E, Gyasi R, Nkrumah K, et al. (2015): Epidemiology of Helicobacter pylori infection in dyspeptic Ghanaian patients. Pan Afr Med J; 20:178 doi:10.11604/pamj.2015.20.178.5024

7. Atapoor S, Dehkordi S and Rahimi F (2014): Detection of Helicobacter pylori in various types of vegetables and salads. Jundishapur. J Microbiol ; 7: e10013. doi: 10.5812/jjm.10013.

8. Bener A, Adeyemi E, Almehdi A, Ameen A, Beshwari M, et al. (2006): Prevalence of Helicobacter pylori infection among low socioeconomic workers.

9. Int J Environ Res; 16(6): 449-54.

10. Cheng H, Hu F, Zhang L, Yang G, Junling Ma, et al. (2009): Prevalence of Helicobacter pylori Infection and Identification of Risk Factors in
Rural and Urban Beijing, China. Helicobacter; 14: 128-33.

11. Dawod HM and Emara MW (2016): Histopathological assessment of dyspepsia in the absence of endoscopic mucosal lesions. Euroasian J Hepato-Gastroenterol; 6 (2):97102.

12. Dore MP, Sepulveda AR, El-Zimaity H, Yamaoka Y, Osato MS, et al. (2001): Isolation of Helicobacter pylori from sheep-implications for transmission to humans. Am J Gastroenterol; 96(5):1396- 1401.

13. Dyer C (2007): A Suffolk farmer in the fifteenth century. Agricultural History Review; 55 (1): $1-22$.

14. El-Gohary AH, Yousef MA, Mohamed AA, El-Amaiem WEA and Abdel-Kareem LM (2015): Epidemiological Study on H. pylori in Cattle and Its Milk with Special Reference to its Zoonotic Importance. Biol Med (Aligarh); 7 : 251.

15. Http://doi: 10.4172/0974-8369.1000251

16. El - Sharouny, El - Shazli H and Olama Z (2015): Detection of Helicobacter pylori DNA in Some Egyptian Water Systems and Its Incidence of Transmission to Individuals. Iran J Public Health; 44 (2): 203-10.

17. Emara MH, Salama RI and Salem AA (2017): Demographic, Endoscopic and Histopathologic Features among Stool H. pylori Positive and Stool H. pylori Negative Patients with Dyspepsia. Gastroenterol Res; 10 (5): 305-10.

18. Fahmy SI and El-Sherbini AF (1983): Determining simple parameters for social classification for health research. Bulletin of the High Institute of Public Health; 235:1-14.

19. Ford AC and Moayyedi P (2008): Current guidelines for dyspepsia management. Dig Dis; 26 (3): 225:30

20. Fujimura $\mathrm{S}$, Kawamura $\mathrm{T}$, Kato $\mathrm{S}$, Tateno $\mathrm{H}$ and Watanabe A (2002): Detection of Helicobacter pylori in cow's milk. Lett Appl Microbiol; 35:504-7.

21. Hamrah MH, Hamrah MS and Hassan Hamrah 
(2017): Prevalence of Helicobacter pylori infection in dyspeptic patients in Andkhoy Afghanistan. Asian Pac J Cancer Prev; 18:31237.

22. Kao CY, Sheu BS and Wu JJ (2016): Pathogenesis. Biomed J; 39: 14-23.

23. Khedmat $\mathrm{H}$, Karbasi-Afshar $\mathrm{R}$, Hossein Khedmat, Agah S and Taheri S (2013): Helicobacter pylori infection in the general population: A middle eastern perspective. Caspian J Intern Med; 4: 745-53.

24. Lehours P and Yilmax O (2007): Epidemiology of Helicobacter pylori infection. Helicobacter; 12:1-3.

25. Mathewos B, Moges B and Dagnew M (2013): Seroprevalence and trend of Helicobacter pylori infection in Gondar University Hospital among dyspeptic patients, Gondar, North West Ethiopia. BMC Res Notes; 6: 346.

26. Momtaz H, Dabiri H, Souod N and Gholami M (2014): Study of Helicobacter pylori genotype status in cows, sheep, goats and human beings. BMC Gastroenterol; 14: 61.

27. Nurgalieva $Z$, Malaty $H$, Graham D, Almuchambetova $\mathrm{R}$, Machmudova $\mathrm{A}$ et al. (2002): Helicobacter Pylori Infection In Kazakhstan: Effect Of Water Source And Household Hygiene. Am J Trop Med Hyg; 67(2): 201-6.

28. Pranjal SR and Kalpana KM (2015): Histological identification of Helicobacter pylori: comparison of staining methods, Int J Med Res Rev; 3 (10): 1167-73.

29. Safaei GH, Rahimi E, Zandib A and Rashidipour A (2011): Helicobacter pylori as a zoonotic infection: detection of H. pylori antigens in milk and faces of cows. J Res Med Sci; 16: 184-7.

30. Santos IS, Boccio J, Santos AS, Valle NC, Halal CS, et al. (2005): Prevalence of Helicobacter pylori infection and associated factors among adults in southern Brazil: a population-based cross-sectional study. BMC Public Health; 5: 118.

31. Sheikhian A, Ataherian S, Delfan M,
Ebrahimzadeh F and Pournia Y (2011): Prevalence and risk factors of Helicobacter pylori infection among Health Center Referrals in Khorramabad (west of Iran). Asian J Epidemiol; 4: 1-8.

32. Shi R, Xu S, Zhang H, Ding Y, Sun G, et al. (2008): Prevalence and risk factors for Helicobacter pylori infection in Chinese populations. Helicobacter; 13: 157-65.

33. Stanghellini V, Chan FK, Hasler WL, Malagelada JR, Suzuki H, et al. (2016): Gastroduodenal disorders. Gastroenterology; 150: 1380-92.

34. Tarkhashvili N, Beriashvili R, Chakvetadze $\mathrm{N}$, Moistsrapishvili $\mathrm{M}$, Chokheli $\mathrm{M}$, et al. (2009): Helicobacter pylori infection in patients undergoing upper endoscopy, Republic of Georgia. Emerg Infect Dis; 15: 504-5.

35. Tongtawee T, Dechsukhum C, Leeanansaksiri W, Kaewpitoon S, Kaewpitoon N, et al. (2015): Improved Helicobacter pylori Eradication Rate of Tailored Triple Therapy by Adding Lactobacillus delbrueckii and Streptococcus thermophilus in Northeast Region of Thailand: A Prospective Randomized Controlled Clinical Trial: Gastroenterology Research and Practice ;Volume 2015, Article ID 518018, 7pages. http://dx.doi.org/10.1155/2015/518018

36. Vu C and Ng YY (2000): Prevalence of Helicobacter pylori in peptic ulcer disease in a Singapore hospital. Singapore Med J; 41: 47881.

37. Whittle DO, Ewing R and Lee MG (2010): The prevalence of Helicobacter pylori infection in patients undergoing upper gastrointestinal endoscopy in the Turks and Caicos Islands. West Indian Med J; 59: 309-11.

38. Windsor HM, Abioye-Kuteyi EA and Leber JM (2005): Prevalence of Helicobacter pylori in indigenous western Australians: comparison between urban and remote rural populations. Med J Aust; 182: 210-3.

39. World Medical Association (2004): Ethical Principles for Medical Research Involving 
Human Subjects (aka the Declaration of Helsinki). Available at www.wma.net.

40. Zamani M, Vahedi A, Maghdouri Z and ShokriShirvani J (2017): Role of food in environmental transmission of Helicobacter pylori. Caspian $\mathbf{J}$ Intern Med; 8(3): 146-52.

41. Zaterka S, eisig, JN and Chinzon D (2007): Factors related to Helicobacter pylori prevalence in an adult population in Brazil. Helicobacter; 12: 82-8.

42. Zhong Y, Anderl F and Kruse T (2016): Helicobacter pylori HP0231 influences bacterial virulence and is essential for gastric colonization. PLoS One, 11: e0154643. https:// doi.org/10.1371/journal.pone. 0154643 